\title{
EL TIEMPO PROFUNDO EN \\ ESCRITOS EN LA CORTEZA DE LOS ÁRBOLES DE JULIA UCEDA
}

\author{
DEEP TIME IN ESCRITOS EN LA CORTEZA \\ DE LOS ÁRBOLES BY JULIA UCEDA
}

\author{
María Teresa Navarrete Navarrete \\ Universiteit Gent / Universidad de Cádiz
}

Resumen: El artículo analiza el poemario de Julia Uceda Escritos en la corteza de los árboles, prestando atención al concepto de «tiempo pasado» que aparece en sus versos. La indagación en el tiempo pasado conduce al desvelamiento de otros horizontes. Estos poemas nos llevan a reflexionar sobre el origen del lenguaje, a buscar en el presente marcas del pasado, a sumergirnos en ámbitos no regidos por las normas de lo real para conocer un tiempo remoto e incluso ignoto, o a revisar la historia pasada. Estas características que se asocian al tiempo pasado son el resultado de una larga indagación lírica que comienza en Del camino de humo y que culmina en este poemario.

Palabras clave: Julia Uceda; Escritos en la corteza de los árboles; tiempo profundo; pensamiento no dirigido; la búsqueda del origen.

Aвstract:This article analyses Julia Uceda's Escritos en la corteza de los árboles, with particular attention to the concept of «past time». The exploration of past time leads to disclosure of other horizons. These poems made us reflect on the origin of human language, seek some trail of the past behind the present, dive to areas beyond the rules to reality to find out ancient even unknown time, or revise the history. These features associated with past time are the result of a long lyrical inquiry that it begins with Del camino de humo and ends with this poetry book.

KeY-Words: Julia Uceda; Escritos en la corteza de los árboles; deep time; dream or phantasy-thinking; the search for origin. 


\section{ALGUNAS NOTAS PREVIAS SOBRE \\ EL CONCEPTO DE «TIEMPO» EN \\ LA POESÍA DE JULIA UCEDA}

«Quizá divertida, me pregunto cuál será la razón del atractivo que sobre mí ejerce ese pasado que, por otra parte, está en todos nosotros. Todos lo llaman recuerdos, pero no son recuerdos» (Uceda, 2013b: 9). Reproduzco esta cita para abrir este ensayo sobre Escritos en la corteza de los árboles porque, si hay algún concepto que ha primado en la poesía de Uceda, ese ha sido el de «tiempo» y, más concretamente, el de «tiempo pasado». La indagación de la poesía ucediana en el pasado se ha realizado de diferentes formas. Se ha atendido al pasado individual del propio sujeto, al que en ocasiones se busca, como en Campanas en Sansueña (1977) o en Viejas voces secretas de la noche (1981), y en otras se rechaza, como ocurría en Poemas de Cherry Lane (1968); al pasado colectivo del ser humano, que la hablante lírica ha vislumbrado en marcas del presente en Del camino de humo (1994); y a un pasado anterior al pasado, más que ancestral, ignoto, tal y como aparecía en Hablando con un haya (2010). El pasado, sin duda, ha sido, y va a ser también en este volumen, una de las señas de identidad de los versos de Julia Uceda.

Por ello, la hablante lírica ucediana se ha entregado tantas veces al laberinto de la memoria. En él, se concentran las imágenes del pasado remoto que contiene presencias olvidadas y ausencias vivas. El recinto de la memoria se distancia en gran medida del recuerdo. El recuerdo concentra los fotogramas que el individuo ha ido acumulando a lo largo de su vida, pero, al margen de este ámbito, queda todo lo que no ha sido experimentado. Para llegar a lo que existe - o existió-, pero se desconoce, es necesario sumergirse en la memoria. En una entrevista con Jesús Vigorra, Uceda contaba que entendía el ejercicio de la poesía como «viajar al fondo del mar con una linterna» (en Vigorra, 2007). Esta comparación entre la búsqueda poética y la búsqueda en los abismos del mar podría asociarse también con la búsqueda en la memoria. Las sombras que dominan estos abismos oscuros se disipan gracias al ímpetu por conocer, por descubrir lo desconocido. Este afán de conocimiento, tantas veces señalado como rasgo definidor de la poesía de Uceda —recordemos, por ejemplo, el título que eligió Miguel GarcíaPosada para resumir la trayectoria literaria de la autora, "Una aventura del conocimiento» (2006)—, se vincula con la luz. De ahí que 
Uceda integrara en su metáfora de la creación poética la presencia de la linterna.

Insisto sobre este símbolo por su plasticidad. Con él, podemos entender fácilmente la naturaleza de la búsqueda que el yo poético de Escritos en la corteza de los árboles va a emprender a lo largo de sus páginas. La frecuencia con la que podemos afiliar estos versos a la indagación en niveles de la memoria profunda nos hará recordar esta máxima que, a mi juicio, se convierte en el punto de partida de este volumen. Acudo a los versos del poema «Linterna» a modo de ejemplo de lo que vengo explicando:

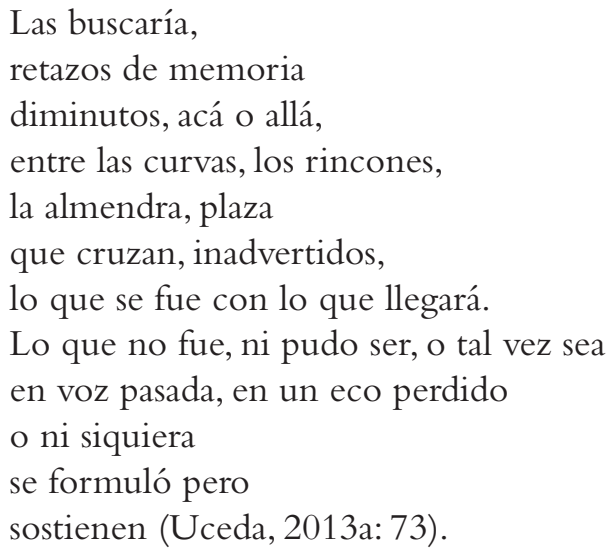

La recuperación de estos retazos de la memoria, de estos ecos de lo perdido, de estos retales de aquello que fue sin ser, se configura como la motivación lírica de este poemario. De acuerdo con Javier Lostalé (2014: 28), esta línea conceptual se advierte, ya de entrada, desde el título. Estos poemas se conciben como una acción contra el olvido, como lo fue la escritura en sus orígenes:

escribir a toda prisa unas notas, unos poemas en este caso, en trozos de las cortezas de los árboles como si fueran hojas desenganchadas de un cuaderno abandonado por alguien. Pero lo primero que se tuvo necesidad de escribir, tanto en las tablillas de barro o madera como en las de corteza de árbol, no habían sido poemas sino datos que, en los templos o en los palacios, era necesario archivar. Las primeras cortezas de abedul, escritas en latín, se encontraron en la fortaleza romana de Vindolanda, al norte de Inglaterra, así como la primera epopeya, en tablillas de barro, fue Gilgamesh (Uceda, 2013b: 29). 
El párrafo reproducido pertenece al prólogo, «¿Somos quienes quisimos ser?», que acompaña a Escritos en la corteza de los árboles. En este texto, Uceda expone el cauce de su trayectoria, que desemboca en la poesía de este volumen. En este sentido, la explicación sobre el título nos ayuda a comprender la intención que sirve de base al resto de los poemas. En ellos se relata la búsqueda de aquel pasado contenido en la memoria profunda. Pero la experiencia lírica va más allá. En estas piezas el yo lírico revive una vida en el pasado, preguntándose por los orígenes de la vida y del lenguaje. Para transmitir esta vivencia, el poema se asimila a aquellas cortezas de abedul de Vindolanda. En resumen, Escritos en la corteza de los árboles trata de exponer el pasado, revivido en los túneles de la memoria, a través de la palabra poética.

\section{EL ORIGEN DEL LENGUAJE}

No es la primera vez que Uceda se pregunta por el origen de las cosas. Desde Zona desconocida (2006) se aprecia un interés especial por la palabra. De este volumen, me gustaría recuperar el poema «La primera». Sus versos abrían un interrogante de difícil respuesta: «¿Cómo lo dijo, / cómo encontró los sonidos en su boca de barro, / y ordenó el aire en su pecho, / lo reunió todo con ritmo y orden / para ser entendido?» (2006: 55). Como vemos, la poeta se preguntaba por uno de los grandes enigmas lingüísticos: el origen del lenguaje articulado. «La primera» se establece como el comienzo de una reflexión lírica que continúa. Si acudimos al prólogo de Escritos..., advertimos la siguiente afirmación:

no se tenían, en un principio, voces articuladas sino sonidos que, de algún modo, se fueron separando de los emitidos por el resto de los que vivían, pájaros, árboles, o no vivían, como las tormentas y la lluvia. Este es un viejo problema no resuelto por los lingüistas (Uceda, 2013b: 30).

La preocupación por el origen de la palabra no queda aquí. Si hasta ahora la autora se había preguntado por el establecimiento de la comunicación oral, el siguiente paso fue pensar en la comunicación escrita.Y, de la misma manera que en el caso anterior, nos propone una revisión desde el origen. Si continuamos leyendo el prólogo, nos encontramos con que Uceda señala que la poesía «la 
ha ido llevando al pasado absolutamente imperfecto hasta imaginar una escritura anterior a la propia escritura: signos en la corteza de los árboles» (ibíd.). He aquí un asunto lírico que Uceda ha ido desarrollando paulatinamente en poemarios anteriores. Quizá el inicio de este procedimiento tengamos que buscarlo en Del camino de humo. Allí, la pieza "Busco señales en la piedra...» descubría un nuevo canal poético en la poesía ucediana. La poeta analizaba el espacio presente en el que se encontraba hasta encontrar marcas con las que pudiera comunicarse con un pasado remoto. Estas marcas — «señales en la piedra», las llamó en Del camino de humo- se perciben por Uceda como el origen primitivo de la palabra escrita. Estas marcas no pueden equipararse a los signos lingüísticos, es cierto, pero sí al icono o al símbolo, capaces de transmitir un contenido semántico. A partir de "Busco señales en la piedra...", Uceda continuó por esta senda reflexiva y en Hablando con un haya aparecen poemas como «Ostracas» o «Papyros» (Uceda, 2010: 45, 52-53), que, si bien no nos hablan de marcas espaciales procedentes del pasado, esto es, de la escritura antes de la escritura, sí dedican sus versos a señalar la preservación de una escritura que data del pasado y que es capaz de comunicarse con el presente.

A esta pareja, sonido y forma, le falta un tercer integrante cuando hablamos del lenguaje: el pensamiento. El poema «Pensamiento, forma, sonido» viene a completar esta reflexión. Recapitulemos lo dicho hasta ahora, para avanzar en nuestro propósito. Si Uceda se pregunta por el origen del habla y de la escritura, debemos pensar a qué atiende esta necesidad. En este punto, pienso que puede ser de utilidad recordar algunos poemas de Extraña juventud (1962). Quizá parezca que me excedo en la retrospección, pero sorprende ver en los versos iniciales de Uceda la imposibilidad de reconciliar la palabra (forma y sonido) con el pensamiento. Cito el comienzo de dos poemas, «La caída» y «Diáspora». El primero decía: «Hay que ir demoliendo / poco a poco la sombra / que vemos. Que nos dieron. / Que nos dijeron “eres”» (Uceda, 1962: 15); y el segundo: «Si supieran qué indican cuando me indican... / Quién puede asegurarme que no soy solo un nombre» (ibíd.: 23). Estas composiciones, dejando al margen la ruptura ideológica con el franquismo que yace en ellas, plantean la falta de coincidencia entre palabra y pensamiento. La palabra que a este sujeto lírico le otorgaban para certificar su existencia distaba mucho del significado real y verdadero que definía su identidad. Esta imposibilidad de ajustar palabra 
y pensamiento se planteaba en Extraña juventud desde la frontera de la recepción. Es decir, el sujeto recibía palabras que no casaban con su pensamiento. Sin embargo, la hablante lírica también se ha visto en la frontera opuesta. En ocasiones, no ha sido capaz de otorgar palabra a su pensamiento. A veces, porque no se puede dotar de existencia - de palabra - a lo que no la tiene, tal y como ocurría en "Noroeste», de Poemas de Cherry Lane (1968: 7-8), o porque el sujeto indagaba en territorios donde la lógica de la realidad no funcionaba. Me refiero, sobre todo, a esas parcelas de percepción instaladas en las normas del pensamiento no dirigido ${ }^{1}$, concepto que se pone en práctica en la lírica de Uceda desde Del camino de humo. En estas zonas el lenguaje se debilitaba y el sujeto no encontraba palabras para lo percibido. El poema «Pensamiento, forma, sonido» retoma esta incapacidad:

1 Jung distingue entre dos tipos de pensamiento: el pensamiento dirigido y el pensamiento no dirigido. El pensamiento dirigido lo define Jung como aquel que se articula a través del lenguaje. Se concibe como aquel que se construye con palabras, que se desarrolla a través del habla y que tiene como finalidad la comunicación. Es decir, este tipo de raciocinio posee una voluntad de exponer, de enseñar, de convencer, de dirigir su actividad hacia fuera. Sin embargo, junto a este tipo de pensamiento nos encontramos con aquel otro que no está dirigido. Cuando tiene lugar el pensamiento no dirigido, «le falta a nuestro pensamiento la presentación superior y el sentimiento de dirección que de ella emana.Ya no imponemos a nuestros pensamientos un itinerario determinado, sino que los dejamos flotar, hundirse o subir por su propia densidad» (Jung, 2009: 41-42). Aunque esta definición nos pudiera parecer, de primeras, imprecisa y algo vaga, Jung asocia el pensamiento no dirigido con el sueño. En las primeras páginas de su estudio, Jung apela a nuestra experiencia como soñantes y alude a las imágenes de los sueños como secuencias que asimilamos de manera natural (ibíd.: 31). Este procedimiento psíquico lo realizamos a diario y no tiene nada de extraordinario, características que Jung quiere destacar con el fin de situar el pensamiento no dirigido, no como un hecho excepcional, sino como una formulación psíquica tan frecuente y tan propia de lo humano como el pensamiento dirigido. Aunque ambos están al mismo nivel, los ámbitos en los que se desarrollan son diametralmente opuestos. El pensamiento no dirigido no es agotador, se desenvuelve sin esfuerzo; no toma como punto de partida la lógica de la realidad, sino que abandona el terreno de lo real y se pierde en las fantasías del pasado y del futuro; no se expresa con palabras, sino con imágenes, con sensaciones o con sentimientos; y su material no se ordena de forma lógica o secuenciada, sino que se aleja de estos términos y, gracias a ello, sus peculiares ordenaciones permiten que nos encontremos con el «pasado con sus miles de recuerdos» (ibíd.: 42). Esta dualidad conformada por el pensamiento dirigido y el pensamiento no dirigido aparece por primera vez en la poesía de Uceda en Del camino de humo. En la pieza «Dos clases de pensamiento in days gone by" se elabora poéticamente esta distinción de la que Julia Uceda se seguirá sirviendo en próximos poemarios, también en Escritos en la corteza de los árboles. 
No se formularon

las palabras que necesito: el pensamiento

vaga y se rebela hasta encontrar sus formas

pero no...

Solo puede

contemplar el silencio, su manto de espuma,

envolverse en un ya vendrán o

las dirá alguien

algún día. Pero no estaré ni habré dicho

lo que quiso decir, pues se quedó enrollado

en su forma de bruma.

Mira las piedras por si ellas...

...y no llegan porque no pertenecen

a idioma alguno todavía, esas

palabras, hasta que algún poeta las encuentre,

¿por qué

entre sonido y pensamiento si este

es claro, y en el lugar del corazón

y la materia que es

estableció su morada? Si el velo

que lo aísla del sonido es suave,

casi transparente, casi

nada, y cae desde la misma nube (Uceda, 2013a: 67).

Como he señalado, en este poema se congregan los tres elementos que coinciden en la formación del lenguaje: sonido, forma y pensamiento; y, además, recae en uno de los callejones sin salida más transitados en la poesía ucediana: la incapacidad del lenguaje para transmitir el pensamiento. «Pensamiento, forma, sonido» nos habla de la falta de funcionamiento de la palabra en los espacios del pensamiento no dirigido. No solo el sujeto lírico relata sus inmersiones en estas profundidades psíquicas, también nos ofrece una galería de personajes, en los poemas «Bocetos», «Kadish» y «¿Qué se oye? (Cero)", que deambulan por lugares a los que la palabra no tiene acceso.

Por ejemplo, en «Bocetos» se nos presenta a una mujer incapaz de asumir su mismidad en el espacio de la realidad. A medida que los versos avanzan, percibimos cómo el poema se instala en los espacios psíquicos del pensamiento no dirigido. Su división en tres partes permite apreciar las fases de este proceso. La primera sección muestra la imposibilidad de reconocimiento en los límites de la realidad que impera en este personaje femenino. No es capaz de 
asumir su rostro frente al espejo, ni siquiera el nombre con el que se la designa: «Ni ella / su rostro conoció: huía hasta del nombre / que le dieron» (ibíd.: 47). Esta situación la encamina a renunciar a la realidad. En la segunda sección, empieza a vivir en su interior y descubrir el origen del mundo en él, y también el del lenguaje: «Repetía / sonidos articulados hacia palabras / que antes nadie había dicho / recordando lo que desconocía y vivieron otros y los mismos» (ibíd.: 48). Este ensimismamiento del yo con su mundo interior la coloca en una posición de incomprensión con respecto a la vida real; pero le permite conocer lo primitivo, lo original y lo pretérito. La tercera parte se inicia de la siguiente forma:

La acompaña el dios de las fronteras aunque no tenga ninguna que cruzar y se haya olvidado de quienes las vigilan.

Mendiga es de palabras y gestos que la expliquen, de sonidos para poder llegar al mundo de los hombres que lanzan signos al aire como un mago palomas de colores; conoce sus sentidos en todos los tiempos que transitaron, aunque haga mucho que se hundieran en la herida de un paisaje helado, cementerio de lenguas pretéritas, perdidas sin ritos: sonidos que se apagaron sin llegar a un destino por humilde que fuera (ibíd.: 48-49).

En estos versos finales, hay un fragmento que esgrime una distinción entre la expresión que nombra el pensamiento dirigido y aquella otra forma de lenguaje que inunda los espacios gobernados por aquel otro pensamiento separado de la realidad. Son tantas las realidades nuevas que las palabras tienen que nombrar, que estas se perciben como signos tan insignificantes como las palomas de colores que lanza un mago.

El poema «Kadish» avanza en esta misma línea. El kadish preserva el carácter mágico de la palabra. Su pronunciación eleva el panegírico a Dios. De ahí que se coloque un poema como este a modo de contrapeso a los versos citados de «Pensamiento, forma, sonido». «Kadish» elige a un niño como representante de esta caracterización mágica del lenguaje. La oración y el mundo infantil se contemplan como ámbitos afines al de la palabra incorrupta. El niño de este poema representa el lenguaje prenatal, otro rastro del origen mágico de la palabra. «¿Qué se oía? (Cero)» sigue esta misma estela. Refiriendo la importancia del origen a partir de una 
cita del momento de la creación procedente del Popol Vuh, nos aproxima al descubrimiento del principio del mundo a través de la experiencia meditativa de una mujer. Todo aquel pasado primitivo está contenido en las galerías de la psique, afirma el sujeto poético, y aunque lo que se percibe no se sepa nombrar, esto no niega su existencia:

Nada supo de ese otro ruido, chal de signos, que la entibiaba porque nacía en su interior: desde el agua y la tierra, de la raíz y el barro de temporales de una edad perdida que creía innombrable. Más tarde, alguien le puso nombre: la creyó.Y se oyó. Ella nunca lo supo (ibíd.: 71-72).

Sin embargo, este ámbito del pensamiento no dirigido no es el único en el que las capacidades del lenguaje se debilitan. Uceda también dirige su mirada hacia la realidad, lugar que a priori es el hábitat del lenguaje. Los poemas «Conocer» y "Animal miedoso» nos muestran el agotamiento de la palabra cuando se utiliza para nombrar realidades engañosas. El eufemismo se percibe como la carcoma. Disminuye el significado de la palabra hasta convertirlo en vacío, en silencio. La palabra, el gran soporte de la comunicación del pensamiento racional, obstaculiza el entendimiento. «Conocer», de tan solo tres versos, lo resume del siguiente modo: «Recogió las palabras de su boca / y después las palpó. Aun así no supo / qué le quiso decir que nunca más diría» (ibíd.: 41). Insiste en esta misma idea «Animal miedoso» en su comienzo: «Buscan / palabras vivas, pero todas / están chupadas, babeadas, opacas de humedad, de testamentos» (ibíd.: 51). De acuerdo con Isabel Mercadé (2014: 58), estos poemas señalan la perversión del lenguaje y, por ello, en este volumen domina el rastreo de lo primigenio, de lo sagrado, de lo que no se ha corrompido; en definitiva, de aquellas primeras palabras escritas en la corteza de los árboles.

\section{ESPACIOS ANTERIORES AL PASADO}

A la reflexión sobre el origen del lenguaje le siguen otras búsquedas. El interés se dirige hacia ámbitos desconocidos que se sitúan más allá de la realidad. El poema que inaugura Escritos en la corteza 
de los árboles demuestra que la curiosidad de Uceda por estos ámbitos no se limita a la escritura. «Kairós» recoge en sus versos una anécdota infantil.Julia Uceda se preguntaba, siendo niña, «¿dónde / estaba yo antes de estar aquí?» ante el nacimiento de sus hermanos. Esta pregunta se recupera de los recuerdos para señalar que existe otro lado, otra frontera de la que prescindimos en nuestra percepción del mundo, pero en la que quizás pueda situarse el origen, el kairós:

La niña se pregunta y pregunta

a los mayores: ¿dónde

estaba yo antes de estar aquí?

Su pasado en no ser estaba en antes, ¿dónde ese antes deshabitado?

¿Y por qué los mayores

evitan responderle?

Ni una pestaña de sus ojos sabe

dónde la niña estuvo.

Ni les importa (Uceda, 2013a: 39).

El pasado del pasado en el que todavía no se es en el ámbito de la realidad y se vive en un antes deshabitado se convierte en el espacio por conocer. La crítica acoge este poema como la insignia de este volumen. Su claridad a la hora de distinguir un foco apartado de la materialidad de lo real, que se concibe como una raíz desconocida de la que brota la existencia, provoca que «Kairós» goce de comentarios en todas las reseñas de Escritos en la corteza de los árboles que se han escrito hasta el momento. Braulio Ortiz Sevilla (2013), Santos Domínguez (2013), Antonio Puente (2014), Isabel Mercadé (2014) y Blas Sánchez Dueñas (2014) insisten en señalar la manera en la que "Kairós» descubre un ámbito desconocido, por el que todos nos hemos preguntado alguna vez. Por su parte, Suárez Plácido (2014) le otorga a este interrogante, "¿dónde / estaba yo antes de estar aquí?», un valor proemial que se extiende a lo largo de todo el poemario al definir «el concepto mismo de preguntarse» y «la necesidad de encontrar respuestas».

Habría que añadir, a esta línea de materiales básicos de Escritos en la corteza de los árboles, el ya citado afán de conocer lo desconocido. De acuerdo con Santos Domínguez (2013), la búsqueda 
invade las páginas de este libro. Antonio Puente (2014) explica esta motivación poética a través de una cita de Jung que Uceda recoge en el ensayo que precede a estos poemas. La cita, que corresponde a Arquetipos e inconsciente colectivo, dice así: «Una vez que se ha hecho todo lo que se pudo hacer, queda todavía lo que se podría hacer si uno tuviera conocimiento de ello» (2009: 38). Estas palabras ponen el foco sobre lo que no sabemos que existe, aquellas realidades separadas de nuestra cotidianidad material que Uceda viene persiguiendo en sus poemas desde Del camino de humo. Esta búsqueda, convertida desde el año 1994 en uno de los principios básicos de la poesía ucediana, lleva a la autora, en una entrevista que mantuvo con Ortiz Sevilla, a establecer sobre este eje una distinción fundamental en el comportamiento vital del poeta:

Uceda diferencia entre «los escritores de versos que se desenvolvían entre realidades concretas y verificables» y el poeta, según su criterio «una persona desamparada que no sabe por dónde va ni adónde, ni quién le empuja, ni qué busca», y de ahí que su obra, como lo es esta nueva entrega, llame a las puertas de lo desconocido (Ortiz Sevilla, 2013).

Prosigo mostrando cómo Uceda configura estos ámbitos desconocidos fuera del tiempo y del espacio en este volumen. Para ello, hay que pasar por los versos de "Círculos», poema que se yergue, a mi juicio, como el gran representante de esta temática. El título hace referencia al círculo, figura arquetípica de unidad, integridad, terminación y perfección. Pero, junto a ello, también el círculo se acoge como la «realidad invisible», «una nada redonda que, paradójicamente, es la fuente primordial de todo» (Ronnberg, 2010: 52). Uceda toma este valor simbólico y construye «Círculos» sobre él. En sus primeros versos, se aprecia la aparición del círculo como ese ámbito que se expande, que todo lo acoge y que nace desde la luz - también, arquetípicamente, asociada con el principio de la creación (ibíd.: 102) — hasta una inmensidad que no se puede ponderar: «El círculo se expande desde donde nace / la luz. Se va alejando el límite hacia una mayor serenidad. / Nada es preciso ni seguro» (Uceda, 2013a: 55). La luz circular, principio de la creación, se asocia a renglón seguido con otra de sus representaciones, el mar. De acuerdo con Ronnberg, "[a]ntiguo y primigenio, el océano es la madre de todas las madres, la Gran Rueda en cuyo continente líquido comenzó la vida» (2010: 36). Por ello, «Círculos» prosigue: 
No sé

si bajo el agua insiste el agua (¿es el círculo un mar de alguna parte o de ninguna? Nada es eterno, como siempre). ¿Descansa el mar sobre un suelo de barcos o prosiguen el agua,

sus habitantes, sus objetos, hacia lo más hondo? (Uceda, 2013a: 55).

Al igual que con «Kairós», Uceda utiliza en "Círculos» una imagen del origen que se comprende fácilmente. El yo poético, tras vincular el mar con el círculo, ambos símbolos del principio de la creación, pregunta si debajo del mar que vemos existe otro mar donde el agua prosigue. Nadie dudará de la existencia de ese otro mar abismal de misteriosa oscuridad. El mar profundo y desconocido sirve como metáfora del lugar donde Uceda dirige su poesía. Lo desconocido, la unidad, la totalidad y el origen son los elementos hacia los que una y otra vez se encaminan sus versos. Continúa "Círculos» con un fragmento que puede contemplarse como una definición de esta modalidad poética dirigida hacia la captura de aquello que niegan las normas de la realidad:

«Parece que hablas con los muertos», me dicen. No:

ellos ya nada tienen que decir, guardan sus secretos. Hablo, para dar libertad a lo no dicho. Por eso,

los círculos se alejan hacia más luz, siempre hacia más luz de conocer. Hablo,

lo intento.Y el anillo se expande y se hace borroso

en su alianza con el fuego del sol.Yo solo voy buscando

palabras e historias no nacidas.

Estoy en el entonces, que decía un poeta, como si entonces fuera un lugar fiel, una playa tranquila. En ese entonces, es donde empieza el tiempo. De él no me he movido (ibíd.).

Estos versos nos indican que el lugar de esta poesía se encuentra en la búsqueda del origen, pero, al mismo tiempo, juega a ser cómplice con otras referencias poéticas. Detrás de ese poeta del entonces se esconde José Hierro con «Entonces»², pieza de Tierra sin noso-

2 «Cuando se hallaba el mundo a punto / de que el prodigio sucediese. / Cuando las horas esperaban / que unas manos las exprimiesen, cuando las ramas opulentas / daban su sombra a nuestras frentes. / Cuando en el mundo se morían / todos los tristes y los débiles. / Cuando el soñar, el sentir hondo, cuando el beber ávidamente / la luz, la brisa, el agua, el aire, eran primero que la muerte. Cuando las tardes solitarias, / cuando los árboles más verdes, / cuando las conchas de colores / a nuestras madres sonrientes, / a nuestras novias de ojos grises / como la 
tros (1947) dedicada a buscar ese origen primigenio. Para terminar con "Círculos», aludo a unas palabras que Juana Castro escribió en referencia a este poema. Por su valor conclusivo, condensan la dirección sobre la que la línea lírica de «Kairós» y «Círculos» se sostiene: «La palabra de Julia Uceda es palabra en el tiempo y tras el tiempo, a su lado el dios de los portones y la lluvia, y el humo, y la protohistoria como un manto, entre resplandores y anémonas y música» (Castro, 2014).

Este afán de conocimiento del origen y de lo desconocido provoca que el yo poético de estos versos sea proclive a sumergir su reflexión en los terrenos del no-ser. En este punto, la concepción del no-ser no debe ser asumida desde los términos de la nulidad. El constructo ucediano creado alrededor de la noción del no-ser se relaciona con todo aquel material instalado en el pensamiento no dirigido, no desvelado en los límites de la realidad y, según la reflexión de estos versos, presumiblemente en el ámbito que contenga el origen. Así, en poemas como «Delfines», «Siempre olvida los nombres» $\mathrm{y}$ «Simposio», se observa un salto hacia el espacio del no-ser.

En «Delfines», Uceda recupera una de las representaciones que la mitología griega ofrece de ellos: "Así como la diosa Afrodita nació de las olas y se la representa montada a lomos de un delfín, las aerodinámicas criaturas que están en tan notable armonía con su mundo marino son emisarias del útero del océano, de donde surgió toda la vida» (Ronnberg, 2010: 206). El yo poético de «Delfines», cual Afrodita, deja que sean los delfines los que la guíen por las profundidades del océano. Con ellos, el paso de lo desconocido a lo conocido, de la irrealidad a la realidad, del no-ser al ser, se convierte en un trance sereno: «Los delfines danzaban en el humo,

escama de los peces. / Cuando eran pena y alegría / nuestros amables timoneles / y no existía otro paisaje / que el que alzaba su luna enfrente: mundo que abría cada día / sus lejanías, frutalmente. // (¿Eras así, tan sin palabras / primaverales que te expresen? / ¿Tan de elementos terrenales: / arena, piedra, hierba, nieve? / ¿Nombres de tiempos, de lugares / deshojados diariamente: / piélagos, hoces, montes claros, / octubre, enero, abril, noviembre?) //Yo no te pinto otros colores / que los colores que tú tienes. / ¿Eras así, mi paraíso, / rumor del agua cuando llueve, / hacha que hiere la madera, / fuego que incendia la hoja verde? //Yo no me acuerdo ya de aquello. / Un día tuve que perderte. / Cuando se hallaba el mundo a punto / de que el prodigio sucediese. / Cuando tenía cada instante / un ritmo nuevo y diferente, / cada estación sus ubres llenas, / rebosantes de blanca leche..." (Hierro, 1980: 32-34). 
/ en el vapor de las espumas azules, / pasando del no ser al ser en la emisión serena» (Uceda, 2013a: 57). Este interés por desvelar el no-ser lleva al yo lírico a situar en «Siempre olvida los nombres» su existencia en esta parcela («Es una ausencia la que dice yo soy» [ibíd.: 70]), y en «Simposio» a preguntarse por el tiempo en el que se ubica su existir («¿Cómo saber en qué tiempo he vivido?» [ibíd.: 83]). Pienso que la predilección por estos espacios debe entenderse no como una renuncia al plano de la realidad, sino como una ruptura con un único modo de raciocinio instalado exclusivamente en lo material. En la combinación de elementos, en la conjugación de opuestos, se asienta la configuración del mundo que ofrece Uceda en estos poemas.

A esta idea de unión de opuestos subyace el concepto de "ciclo». La noción del tránsito perpetuo de un lado hacia su contrario se recoge en tres poemas de este volumen. Dos de ellos, a pesar de situarse separados en las páginas de este poemario, comparten esta idea y un mismo subtítulo, «(Formas del agua)». Acoger dos piezas bajo el mismo principio convierte los versos de «Lágrima (Formas del agua)» y «Río (Formas del agua II)» en dos momentos de una misma reflexión que queda delimitada bajo la circularidad del agua. Cirlot, en su conocido Diccionario de símbolos, explica la concepción simbólica atribuida al agua y en ella se observa la importancia de su naturaleza periódica y constante. Sus palabras pienso que ayudan a adentrarse en estos dos poemas:

Dentro de su aparente carencia de forma, se distinguen, ya en las culturas antiguas, las «aguas superiores» de las «inferiores». Las primeras corresponden a las posibilidades aún virtuales de la creación, mientras las segundas conciernen a lo ya determinado. Naturalmente, en este aspecto generalizado, por aguas se entiende la totalidad de materias en estado líquido. Más aún, en las aguas primordiales, imagen de la protomateria, se hallaban también los cuerpos sólidos aún carentes de forma y rigidez. Por esta causa, los alquimistas denominaban «agua» al mercurio en el primer estadio de la transformación y, por analogía, al «cuerpo fluídico» del hombre, lo cual interpreta la psicología actual como símbolo del inconsciente, es decir, de la parte informal, dinámica, causante, femenina, del espíritu. De las aguas y del inconsciente universal surge todo lo viviente como de la madre. Una ampliación secundaria de este simbolismo se halla en la asimilación del agua y la sabiduría (intuitiva). [...] En suma, 
las aguas simbolizan la unión universal de virtualidades, fons et origo, que se hallan en la precedencia de toda forma o creación. La inmersión en las aguas significa el retorno a lo preformal, con su doble sentido de muerte y disolución, pero también de renacimiento y nueva circulación, pues la inmersión multiplica el potencial de la vida (Cirlot, 2006: 68-69).

Los dos poemas se asocian a la noción de "aguas superiores» mencionada por Cirlot. El agua aparece como la fuente del pensamiento original. La inmersión, el baño o la comunión del ser con el agua permiten la transfusión de ese contenido primigenio. Los tocados por el agua se acercan al ámbito de lo inmaterial, de lo desconocido en la percepción habitual de lo real, creando una cadena que preserve la continuidad. Este sentido de sucesión se transmite en «Lágrimas (Formas del agua)» a través de la lágrima: "Gotas esperan ser bebidas / y esperan bocas desde donde / caer del corazón al corazón el vacío / esperan para decir lo nunca confesado / desde el labio que beba» (Uceda, 2013a: 43). El paso del agua de una entidad a otra genera un rastro parecido al que fundan las palabras cuando se propagan por repetición de un lugar a otro. A eso se dedica la segunda parte de esta pieza, «Río (Formas del agua II)»: «No le pongan riendas / al sonido adulto. No le pongan / bozal a las bocas que lanzan ruidos, / piedrecillas, oraciones, salmodias. Ecos / desde cuándo, hasta dónde» (ibíd.: 87). La redundancia en el encadenamiento y en la prolongación de significados a través del agua o de la palabra responde a la necesidad de mantener el tránsito de materiales primitivos a un tiempo presente. Este paso, del pasado al presente, no termina aquí. Es lógico que así sea, si se quiere completar el ciclo. Lo presente se convertirá en pasado cuando llegue el tiempo futuro. Por ello, para resguardarse del olvido, el presente debe dejar sus marcas. Con el presente transformado en pasado, se pone en marcha una nueva fase donde el agua y la palabra funcionan como un río capaz de arrastrar los signos del presente hasta el futuro. Al recuperar la estrofa anteriormente citada de «Río (Formas del agua II)», se observa que el poema eleva la palabra a ser el cauce que deposita el presente en el futuro. La palabra, continúan estos versos, «[s]erá / lo que nos conozca, lo que nos defina / y empape la lágrima / perdida en el agua de un viejo río / sin fondo, sin cauce, sin nombre / - las llaves del tiempo- / al que nadie ha ido a beber todavía» (ibíd.). Ese cauce al que nadie ha ido a beber 
todavía - es decir, el futuro- se concibe como el único recinto en el que el presente puede conservarse. El cordón umbilical entre pasado, presente y futuro se sustenta en un tiempo único gracias a que lo efimero del ahora se supera con las marcas que del tiempo quedan en el espacio. Los últimos versos de «Lágrima (Formas del agua)» concluyen con gran rotundidad: «Porque estamos de paso como si no supiéramos / que hemos venido solo para un día o menos / piedras con iniciales único testamento / amontonado sobre el polvo / nadie entiende» (ibíd.: 43).

La perpetuación del ciclo natural, fundamentado en la vida y la muerte, también se observa en el poema «Sinestesia». Al igual que ocurría en los dos poemas anteriores, el sentido último del poema yace en la necesidad de la renovación perpetua, pero conservando alguna señal de preservación de la fase anterior. «Sinestesia» tiene su origen en una anécdota real de la vida de Julia Uceda. Reproduzco, en primer lugar, el poema para después reconciliarlo con la anécdota que lo propició:

Tina Modotti, mi hermosa gata siamesa, murió de cáncer a los once años, y la enterró en el valle esplendoroso, en primavera, cerca del río, un húngaro, albañil, de nombre extraño: Carlomagno se llamaba. A veces, en la noche, titilan sobre el lugar los siete pétalos de una estrella elusiva (ibíd.: 61).

«Sinestesia» aparece por primera vez en el blog de Fernando Valls, La nave de los locos. Publicado el 1 de junio de 2012, el poema se acompaña de una nota que ayuda a su comprensión:

Julia Uceda bautizó a su gata con el nombre de la fotógrafa Tina Modotti. Me cuenta que era un animal extraordinariamente inteligente, pero padecía mucho con el cáncer que tenía y hubo que sacrificarla. Era, además, sufrida y digna. Cada animal tiene su propio carácter, explica Julia. La enterró un albañil húngaro, llamado Alejandro Magno, que estaba trabajando en su casa. Las palabras, comenta Julia, nos pueden llevar a cualquier lado.

Modotti fue asesinada por el Comandante Carlos, un estalinista. El escritor R. J. Sender lo temía porque durante la guerra civil española se convirtió en la mano de Stalin 
en nuestro país. También estuvo implicado en la muerte de Trotsky.

Ahora, sigue explicándome Julia, están adiestrando a los perros para que detecten el cáncer antes de que dé señales de vida.Y lo conseguirán, me dice: hace unos días vino a casa un amigo que lo había superado recientemente. Y aunque nunca antes nos había visitado, la perra se acercó al grupo de gente, pero se fue hacia él, le acercó la cabeza para que la acariciara y luego le lamió las manos. Después se fue otra vez sin hacerle caso a nadie más.

Dejando al margen la fascinación de Julia Uceda por lo natural, estas palabras sirven para homenajear a su animal de compañía y también a Tina Modotti. Aunque murió, en el lugar donde está enterrada algunas noches puede observarse en el cielo, según nos cuenta el poema, una estrella de siete puntas. Me gustaría señalar la existencia de diferencias entre las dos publicaciones. Varía el nombre del albañil húngaro, Alejandro Magno por Carlomagno, y el número de pétalos - o puntas - de las estrellas, de once a siete. Esta última variante se basa en la idea de totalidad. Si en una primera escritura, la del blog, los pétalos son once y el número concordaba con los años de vida de la gata, en la definitiva se cambia a siete por una razón. Hipócrates definió este número del siguiente modo: «El número siete, por sus virtudes escondidas, mantiene todas las cosas en el ser, dispensa la vida y movimiento, influye hasta en los seres celestiales» (en Chevalier y Gueerbrant, 1999: 942943). La idea de preservación de la totalidad parece encerrarse en este número. De ahí, que Uceda prefiriera transferir la ausencia de su gata en presencia estelar de siete puntas. La transmutación a la que se alude al final del poema explica el título de la composición.

Para terminar, insisto sobre la reflexión que se ha desarrollado en este apartado. Aunque el tiempo pase, sus marcas quedan y en ellas hemos de revitalizar lo perdido. Su aparición se acoge desde estas páginas como un constructo que contiene la fusión del pasado, del presente y del futuro. 


\section{LA HISTORIA COMO ENTIDAD CÍCLICA}

Si, en la búsqueda del pasado primitivo, los poemas de Uceda concluían - tal y como acabamos de ver en el epígrafe anterior- que el tiempo se advierte como una construcción capaz de albergar en su ciclo las fases del pasado, el presente y el futuro, algo muy parecido sucede cuando, en Escritos en la corteza de los árboles, aparecen composiciones de tema histórico. Como bien explicitan los primeros versos de «Palabras y campanas», la Historia también parece plegarse en sí misma. Forma un ciclo donde la paz y la guerra se contemplan como los dos polos que conforman su ecuador. Las guerras aparecen como una fase más del ciclo de la Historia: «Estas no son mis guerras / ni sus rostros me son familiares. / Todo está un poco más atrás, / no mucho, / pues el recuerdo y el futuro caminan / por las mismas sendas» (Uceda, 2013a: 65). Por ello, en este poemario vamos a encontrar la meditación histórica, tan frecuente en los versos ucedianos, ordenada según esta visión cíclica. "Álbum» se enarbola como la pieza que ejemplifica de forma más clara esta conceptualización histórica. Pero, antes de avanzar, y a modo de introducción a ella, nos adentraremos en otros dos poemas, «Rastas» $\mathrm{y}$ «Shirayuky».

En «Rastas», Uceda nos habla de un colectivo que conoció bien durante su estancia en Estados Unidos durante los años sesenta, los hippies. Su representación del mundo rastafari pasa por referir el origen social de los integrantes de este movimiento, en su mayoría hijos de familias burguesas acomodadas. Se desprende de este poema un juicio rotundo hacia el comportamiento de los integrantes de este colectivo. Los hábitos sociales burgueses en lo que se refiere al uso de la ropa, de la música o del consumo de drogas se rechazan y se atisban en estos versos como comportamientos infantiles, algo hipócritas, despolitizados y, sobre todo, fruto de ideales transitorios. Una vez acabada la juventud, los hippies volverán a su origen burgués y actuarán socialmente de acuerdo a su clase:

\footnotetext{
Algo ha cambiado los muebles de sitio (nada es como era en casa de papá).

Les dio por sentarse en el suelo con cacas de perros, papeles con grasa, colillas; a usar chanclas y tenis roídos, dormir en aceras, comer cualquier cosa
} 
vistiendo de pobres sus cuerpos de ricos, paseados, en tiempos, por Harvard o Yale.

Con cautela y arte,

sus rastas echaron al hombro, a la espalda, por la estrella negra cambiaron las cruces (ibíd.: 59).

"Shirayuki», por su parte, puede definirse como un destello del poema "Álbum», más específicamente de su cuarta parte, «Shöwa, paz ilustrada». Esta sección y el poema «Shirayuki» tratan sobre un mismo personaje histórico, el emperador japonés Hirohito. De hecho, «Shirayuki» precede en el volumen a «Álbum». Shirayuki, 'nieve blanca' en japonés, fue el nombre que Hirohito eligió para su caballo predilecto. Estos versos ofrecen una trasposición, visión o delirio — «(porque estoy enferma, me digo)» (ibíd.: 75)— en el que el yo poético se encuentra con el caballo de Hirohito - «El potro blanco, como llama de nieve, / salta hacia la ventana. Estoy allí sin estar» (ibíd.)—.

Si bien «Rastas» $\mathrm{y}$ «Shirayuky» relatan dos episodios históricos muy distintos, ambos comparten el modo en el que se presentan. Aparecen como ráfagas, como fotogramas de la historia occidental del siglo xx. Esta técnica traza el cauce poético de «Álbum». Como nos anuncia el título, las distintas secciones en las que se dividen sus versos funcionan como fotografias de diferentes momentos históricos. De acuerdo con Julia Uceda (2013b: 31), «Álbum» recuerda en su estructura fraccionada a "Moleskine», de Hablando con un haya. Pero, en este caso, cada fotografia, esto es, cada sección, representa en sí misma una unidad que irá hilvanándose a otra de acuerdo con el azar vital de la persona, en este caso el yo poético, que posee el álbum. Las fotografias de este álbum tan particular se titulan «Casas vacías», «1812», «Ventanas», «Shöwa, paz ilustrada»y "Regreso». No nos queda más que contemplarlas. Los comentarios que la autora ofrece en el ensayo "¿Somos quienes quisimos ser?» aparecen como la mejor guía posible.

Empieza Uceda explicando que «Álbum» «recoge y resguarda el pasado en sus tonalidades ahumadas e inexplicables» (ibíd.). En la primera fotografía de ese pasado, "Casas vacías», se perciben hogares desolados de una estepa rusa donde sus habitantes dejaron rastros de lo que algún día fueron sus casas. La precipitada huida a causa de la guerra convierte estos espacios en ámbitos cubiertos por el desamparo: 
Alguien dejó puesta la llave y se ha ido. Nunca regresó.

El barro de unas botas de soldado

ha manchado la alfombra antes

de que el polvo de heno recién cortado

la cubra lentamente para dormir sobre ella

como un perro podrido.

El hueco desolado de las casas vacías, donde, lejos, resuenan

fragores de batallas de otro tiempo,

arrastran el gemido de ruedas de cañones,

o el súbito silencio suspendido

que pende, interminable, de una rama

engastada en nieve. Silencio, el

vacío atravesado por fuegos lejanos,

por el lamento que vigila

el ojo adusto de la noche,

por el dolor de los que ignoran

por qué han de morir y por qué ellos

si el heno huele a hogares, a vodka,

a familias (Uceda, 2013a: 77).

Tras escribir estos versos, Uceda se pregunta:

¿Por qué después de contemplar la fotografía de una casa abandonada en la estepa rusa se han ido citando bajo el mismo título otros espacios, de pasados también, cosidos, podría decir, por un vaso de agua olvidado en una cocina mientras se oyen guerras distintas? No se trata de recursos retóricos. No sé por qué lo hice. Mientras escribía, el vaso se iba haciendo presente y también las guerras. El vaso señalaba que alguien estuvo allí recientemente (más o menos 1812) y el poema está escrito en el siglo xxi (2013b: 31).

El vaso de agua olvidado en la cocina del que nos habla aparece en la última sección de "Álbum», pero antes de llegar a él, pasemos a la segunda fotografia, «1812». A esta fecha que da título a la segunda parte de este poema es a la que Uceda se refiere en el fragmento anterior. La datación precisa de ese poema le permite señalar a la autora que, si bien otros fueron los protagonistas de este tiempo pasado de $1812^{3}$, en la actualidad el yo poético puede ac-

3 La autora utiliza el adverbio «recientemente» para indicar la cercanía con la 
ceder a este ámbito y revisitarlo a través de los versos. Para «1812», siguiendo con la introducción mencionada, Uceda nos ofrece los siguientes datos: «En 1812 Napoleón ha invadido Rusia y es el año de la batalla de Borodinó; Pierre es el conde de Bezukhov que "visita" la guerra» (ibíd.). Tan solo con estas informaciones, las páginas de Guerra y paz de Tolstói se transfieren a estos versos a través de Pierre Bezukhov: «Vio, la casa, a Pierre cuando / (separado del frío por su burka) / entró y salió deprisa por un vaso de agua / el día que llegó a pasear batallas: / Borodinó, fue la más elegante y bien vestida» (2013a: 76-77). Este reflejo se mezcla con las casas de la primera parte, donde el yo poético retrataba hogares abandonados. De aquella Rusia de 1812 solo quedan vacíos en el presente. Pero la hablante lírica quiere restituirlos sirviéndose de la memoria profunda:

La habitación, ojos cerrados, permanece

desde hace siglos esperando

ya no se sabe a quién. Y la contemplo

desde este territorio de la vida,

por si oyera una voz en su silencio,

o el quejido del papel arañado, seco,

que cubre las paredes o la indignada voz del viento

golpeando ventanas. Sacudiendo puertas

que estuvieron y quizá ya no estén (ibíd.: 78).

Este viaje psíquico por el pasado reciente deja un nuevo fotograma en «Ventanas», tercera sección del poema. Estos versos avanzan en el tiempo hasta descansar en el tránsito del siglo XIX al XX. Allí se encuentra con un pintor y un filósofo, Munch y Nietzsche. El primero dibuja ventanas - recordemos cuadros como Kiss by the window (1892) o el fondo de The storm (1893) - y el segundo aparece pensativo, al igual que en su fotografia más reproducida, que data del año 1882: «Allí están / las ventanas que Munch dibuja, sin haberlas visto, a la derecha / del maduro filósofo de Roëken / (cuya vida era un campo de batalla) / sentado y pensativo a quien un día / conoció» (ibíd.). Ese «allí» resulta poderoso en estos versos, ya que consigue congraciar los tiempos y los espacios en un único punto. Uceda lo explica así: "“Allí están / las ventanas” de la primera casa, ¿hemos regresado a ella? Pero no es la misma, sí lo son las

actualidad de este tiempo si lo equiparamos a otras búsquedas poéticas ucedianas instaladas en el pasado primitivo. 
dos ventanas y sus cortinas, en la misma disposición, y es Nietzsche el que está sentado mirando hacia ninguna parte y con la mano en la mejilla» (2013b: 31). Aunque se pueda pensar que Uceda está jugando a la confusión en «Álbum», no creo que sea así. Más bien se trata de fotografiar distintos momentos de una meditación que viaja por los canales de la memoria profunda. En ella, el yo lírico se encuentra con retales de momentos históricos que muestra superpuestos en una misma pieza poética. Prosigue este poema con «Shöwa, paz ilustrada». «Shöwa» —en español, 'paz ilustrada' - fue el título con el que Hirohito fue proclamado emperador. Se rescata su figura de los versos de "Shirayuky»y, al comienzo, su retrato se aproxima al de este poema: «Montoncito de hombre-dios / sobre caballo blanco" (2013a: 79). Sin embargo, la imagen de su figura se recrudece cuando el yo poético recuerda su discurso - era la primera vez que sus súbditos escuchaban la voz del emperadorde rendición en la Segunda Guerra Mundial, con Hiroshima y Nagasaki arrasadas por el bombardeo nuclear:

\section{La derrota}

de su pueblo sagrado, lo primero

que oyeron de su voz. Tuvieron

que verter la refinada lengua de palacio

a la común de los que apoyan sus frentes en la tierra

y comen de los muertos que mataron.

Pero Paz Ilustrada

no dice la verdad — se ha perdido la guerra-

sino deseo

abrir caminos de la paz

a las generaciones del futuro o bien

la obligación que me legaron

antepasados... (ibíd.: 79-80).

Aunque los trazos se siguen superponiendo en versos como «Y vuelvo a preguntarme si el salvador del mundo, / porque eso cree, o dice al menos, leyó a Tolstoi, supo algo de Nietzsche», que incluyen la segunda y tercera sección de "Álbum» en esta cuarta, el objetivo de este fotograma es otro. El abandono, la soledad, la desesperanza de las guerras se intensifican en este fragmento. Se tornan en horror cuando este yo poético toma la fotografia de la Segunda Guerra Mundial. El absurdo de la destrucción se canaliza en la figura de Hirohito, emperador que por gracia de su «divinidad» llevó a su pueblo a una de las mayores tragedias del siglo 
xx. Perdida la guerra, Hirohito renuncia a su divinidad obligado por Occidente y se contenta con ser símbolo del Estado (Heffer y Launay, 1992: 80): «Después de renunciar a su abolengo / de sol y de dragones lo perdonó Occidente; / en el 47 se disoció de su entidad divina. / Fue el mismo año de La peste. / El crisantemo se cubrió de sangre» (Uceda, 2013a: 80). El último verso condensa la corrompida divinidad del emperador. El crisantemo, emblema del trono japonés, se cubre de la sangre de la Segunda Guerra Mundial.

Como se observa, al pasar las fotografias, el horror y el absurdo de la guerra se van intensificando hasta terminar con el bombardeo nuclear. Los efectos de los conflictos bélicos sobre la humanidad se establecen en «Álbum» como el hilo conductor que une estas fotografias. Termina esta revisión con el vaso de agua abandonado en la cocina del que nos hablaba Uceda en su introducción. «Regreso», última sección de «Álbum», pone fin a la retrospección histórica por las galerías de la memoria profunda. El yo poético regresa a su presente, a su cocina; en definitiva, al plano de la realidad: «Fuera, la noche continúa cayendo y se evapora / la sangre, el agua del vaso abandonado» (ibíd.: 81).

Para finalizar, sumando a este propósito el de aunar estos poemas de contenido histórico al resto de las composiciones de Escritos en la corteza de los árboles, me gustaría aludir a un pequeño poema de este volumen, «Si se tala un árbol». La pieza dice así: «Si se tala un árbol / ¿qué sienten sus raíces / perplejas / abandonadas a lo oscuro?» (ibíd.: 53). Precisamente este poemario, con su ejercicio constante de la memoria, con su inmersión en ámbitos psíquicos diferentes a los de la realidad, persigue, si se me permite seguir con el símil, mantener en pie los árboles del pasado remoto y reciente. Lo que se pretende es que no se olvide que todos los presentes se sustentan en un sustrato de hojas marcadas por la escritura de otro tiempo. 


\section{BIBLIOGRAFÍA}

Castro, Juana (2014). «Ecos, sonidos», Cuadernos del Sur, 8 de febrero. http://www. diariocordoba.com/noticias/cuadernos-del-sur/ecos-sonidos_859348.html

Chevalier, Jean y Gheerbrant, Alain (1999). Diccionario de los símbolos, Barcelona, Herder.

Cirlot, Juan Eduardo (2006). Diccionario de símbolos, Barcelona, Siruela.

Domínguez, Santos (2013). «Escritos en la corteza de los árboles», Encuentros con las Letras. Revista de Literatura, 31 de octubre. http://encuentrosconlasletras. blogspot.com.es/2013/10/escritos-en-la-corteza-de-los-arboles.html

García-Posada, Miguel (2006). «Una aventura del conocimiento», en Julia Uceda, Zona desconocida, Sevilla, Fundación José Manuel Lara, pp. 83-104.

Heffer, Jean y Launay, Michel (1992). La Guerra Fría (1945-1972), Madrid, Akal.

Jung, Carl Gustav (2009). Arquetipos e inconsciente colectivo, Barcelona, Paidós.

Hierro, José (1980). Antología, Madrid,Visor.

Mercadé, Isabel (2014). «Escritos en la corteza de los árboles», Quimera, 366, p. 58.

Ortiz Sevilla, Braulio (2013). «De lo que permanece en el silencio»,

Diario de Sevilla, 23 de octubre. http://www.diariodesevilla.es/ article/ocio/1630029/lo/permanece/silencio.html

Puente, Antonio (2014). «Julia Uceda: la vejez como vida prenatal», ARNDigital, 60.

Ronnberg, Amy (2010). El libro de los símbolos. Reflexiones

sobre las imágenes arquetípicas, Barcelona, Taschen.

Sánchez Dueñas, Blas (2014). "Creación poética desde el vacío profundo de lo inefable: Escritos en la corteza de los árboles», Ínsula, 813, pp. 39-41.

SuÁrez Plácido, Rafael (2014). «Palpando palabras. Escritos en la corteza de los árboles», Estado crítico. http://www.criticoestado.es/palpando-palabras/

UCEDA, Julia (1962). Extraña juventud. Madrid, Rialp.

- (1966). Sin mucha esperanza, Madrid, Ágora.

- (1968). Poemas de Cherry Lane, Madrid, Ágora.

- (1977). Campanas en Sansueña, Madrid, Dulcinea.

- (1981). Viejas voces secretas de la noche, Ferrol, Colección Esquío de Poesía.

- (1994). Del camino de humo, Sevilla, Renacimiento.

- (2006). Zona desconocida, Sevilla, Fundación José Manuel Lara. 
- (2010). Hablando con un haya,Valencia, Pre-Textos.

- (2012). «Sinestesia», La nave de los locos. Literatura y más [blog de Fernando Valls]. http://nalocos.blogspot.com.es/2012/06/la-gata-de-julia-uceda.html.

- (2013a). Escritos en la corteza de los árboles, Sevilla, Fundación José Manuel Lara.

— (2013b). «¿Somos quienes quisimos ser?», en Uceda (2013a), pp. 9-32.

Vigorra, Jesús (2007). Entrevista a Julia Uceda [película], Sevilla, Canal Sur de Andalucía. 